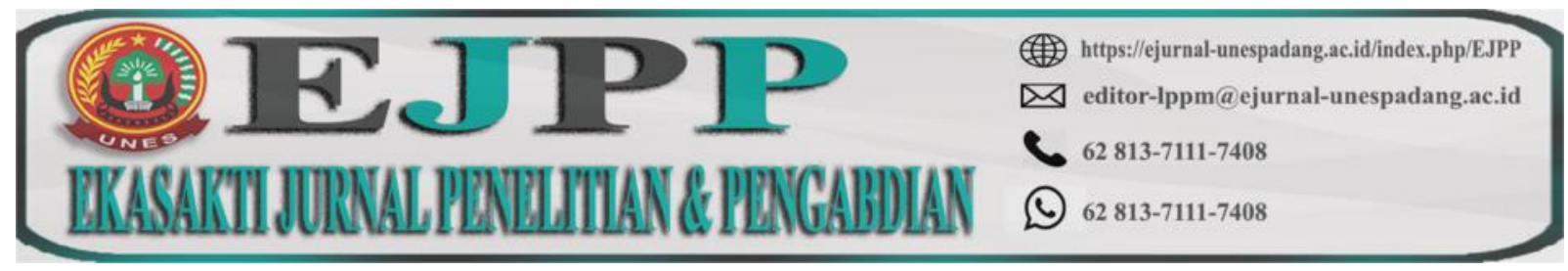

DOI: https://doi.org/10.31933/ejpp.v1i1

Received: 30/09/2020, Revised: 15/10/2020, Publish: 22/11/2020

\title{
SOCIAL DIALECT UTTERED BY INDIA COMMUNITY IN PADANG
}

\author{
Mac Aditiawarman $^{1}$ dan Amelia Yuli Astuti ${ }^{2}$ \\ 1) Fakultas Sastra Universitas Ekasakti Padang \\ E-mail:mac_aditiawarman@yahoo.com \\ 2) Fakultas Sastra Universitas Ekasakti Padang \\ Email: ameliayuli127@gmail.com
}

\begin{abstract}
ABSTRAK
The ethnic customs of India in speaking and communicating have been accustomed to mixing their mother tongue with Minangkabau language, so that there has been a mixture of vocabulary that they say. Because the mixes are so swift, there has been mixed code-mixing in their language. The approach in researching this problem is used in sociological. The purpose of this study is to explain the language changes that occur among ethnic Indians in the city of Padang. Techniques of collecting data, among others, by using qualitative methods. The results of the research conducted, the writer finds language changes that are influenced by Minangkabau language, Chinese Padang language and Indonesian language. The changing that occur among others, change vowel /i/ become lel in the middle of the word, disappearance of consonant $/ \mathrm{h} /$ in the beginning, middle, and end of word. Consonant removal $\mathrm{I} r \mathrm{I}$ in the middle and end of word. The impingement /to/ at the end of the word, vowel /u/ being $/ \mathrm{o} /$ in the middle and end of the word, consonant splitting $/ \mathrm{t} /$ to $/ \mathrm{k} /$, vowel $/ \mathrm{a} / \mathrm{being} / \mathrm{l} /$ the consonant splitting /p/ into /?/, the / $\mathrm{y}$ being/a/ at the end of the word, vowel/e/ being /a/ in the middle and beginning of the word. The disappearance of vowel /el in the middle of the word, the disappearance of consonant/d/ in the beginning and middle of the word, as well as the disappearance of consonant $/ p /$ at the end of the word. The Indians ethnic code mixing can be formulated by using the theory of code mixing.
\end{abstract}

Keywords: Code, Mixing, Change, Ethnic, Intial, Medial, Final, Deletion, Subtitution, Expansion, Permutation, Parapharse 


\section{INTRODUCTION}

Language is the ability to acquire and use complex system of communication, particularly the human ability to do so, and a language is any specific example of such a system. Natural languages are spoken or signed, but any language encoded into secondary media using auditory, visual, or tactic stimuli-for example, in whistling, signed, or braille.

Language is not given since human birth. While human growth, the community around human assist to speak. That is how language is uses, both to interact or to communicate. The complex system of language communication became language have many problem into interactional in social life one of the problem is language changes. Trask (1994:2) explains that every living language is constantly changing, in vocabulary, in pronounciation, and in grammar, this change is natural and inevitable, and it should not be grounds for alarm or condemnation. These describe that changing in language is usually happen.

Language is always changing. Through the modern era, new words are constantly to be use, at the same times old words gradually dropping out of use. These related to the problem of language change, because of the surrounding around. Older speaker usually use the original language has passed away. So the language itself is rarely to be used in this modern era. Only a few people which are still use the language.

In the other side, as a minority community, India people who lived in Padang make their own language for communication. By the time, the original language has changed because India people have to communicate to another, while Padang used Minang language. Nowadays, the writer who have a half blood of India seek and often heard, the India people mix Minang and their original language. The writer see this as one of the unique language. For simply example, the India people called a boy with "tambi". Or another example is, if they want to say yor dressed is ugly, they will says 'sotte baju lu kini ko ma". The writer purpose is to preserve this uniqueness from extinction.

In focussing the problem, the writer want to analyze how India community use their language in communication, in interaction, is there any change in their language and the writer also want to see the code mixing that they have in their language. After knowing the code mixing, the writer want to make the formulation of the code mixing itself. This analysis derived from limitations of the problem become the purposes of the research :

1. To describe the language change among India ethnic in Padang

2. To explain briefly code mixing that occur on India people in Padang

3. To describe the formula of code mixing uttered by India people in Padang 
The writer uses sociological approach to reach the point of research question. The writer uses the Chomskyan framework that focuses on structures that could be generated in language and by what means, the social approach tries to account for what can be said in a language, by whom, to whom, in whose presence, when and where, in what manner and under what social circumstances (Fishman 1971; Hymes 1971; Saville-Troike 1982: 8). A distinction that persists (though it is not one that we particularly advocate) is that between the sociolinguistics (proper) and the sociology of language. Language change that properties of language change might be explained by the way language is acquired and structured in the mind, is of course by no means original to generative grammar.

Interestingly, however, Chomsky (1986:16-17) recognizes that homogeneous speech communities do not exists in the real world, and that each individual has acquired a language in the course of complex social interactions with people who vary in the ways in which they speak and interpret what they hear and in internal representations that underlie their use of language. In addition, two people may share exactly the same knowledge of language but differ markedly in their ability to put this knowledge to use (Chomsky 1986:9).

Crowley (1997:154) that describes lexical change is known as etymology. It studies the particular words history rather than the change of actual pronounciation. Furthermore, Crowley says both of the terms refer to the same process. The process of copying words from other languages in one area prefer cultural vocabulary rather than core vocabulary. Core vocabulary is vocabulary which can be found in all human languages (1997:155), while cultural vocabulary is vocabulary which can be found through the experience from everyone's culture.

\section{RESEARCH METHODS}

The research is a largely descriptive linguistic tradition that provides a firm foundation in analyses of genres of writing or text-based interaction, as well as face-to-face interaction, characterized in terms of the choices authors and speakers make about how to present themselves through language. Chamber (2013:21) explain that once the community has been selected for research, the next step is to get a perspective on the community itself - linguistic, demographic, and historical. Information on local speech, major industries, labor, religious institutions, communications, movement of peoples, and the historical development of the area can aid in understanding local society.

A survey of previous linguistic work must be carried out, both on the linguistic aspects you intend to study and on any previous research concerning the local language variety. Earlier work on the local variety, regardless of its quality, can be useful for time depth or for pinpointing interesting problems. The choices that authors and 2 speakers make are mapped out in decision tree representations referred to as systems, which is where it gets its name. The constructs coming from the field of systemic functional linguistics provide us with a common foundation for exploring stylistic norms of conversational behavior across genres of dialogic interactions. What makes it an ideal choice for our efforts is the historical fact that it grew up side-by-side with one of the few sociological theories that was informed by linguistic data. 
As such, in contrast to other existing linguistic theories, it was fashioned specifically for the purpose of explaining sociological processes at multiple levels and within a wide range of contexts. Beyond these social phenomena, mechanisms such as grammatical metaphor endow it with the ability to represent how reasoning processes and conceptual development are displayed through language as well. Thus, it holds the potential to bridge between more cognitively oriented theoretical perspectives from the Learning Sciences as well as more socially oriented ones.

The writer use distributional method for analyzing data. Djajasudarma describes the distributional method using the determinative in a language that is examined in determining basic. The basic of this method is the technique of data selection by category of grammaticalization (especially in descriptive studies) in conform with the natural features. The distributional method rely on the decisive element of language support itself with :
a. Deletion
b. Subtitution
c. Expansion
d. Permutation
e. Parapharse

The writer use qualitative research for collecting data. Qualitative research is a certain tradition in social science that is fundamentally dependent on human observation in its own region and connect with the community through language, with the features:

1. Scientific background, meaning researchers conducted the study in the context of a wholeness that brings research to the study;

2. Humans as tools, observations can be divided into open-ended examination (unknown subject) and closed (unknown subject);

3. Qualitative methods, emphasizing quality (characteristics of natural data) in accordance with the descriptive and natural understanding itself;

4. The study of inductive data analysis, data is assessed through a process that goes from fact to theory, not vice versa;

5. The basic theory, using inductive study refers to data search / data collection. This study is more of a formation abstract, based on the parts have been collected and then sorted, while the deductive method in language research carried out by formulating a hypothesis first, and then test it with data;

6. Descriptive, the collected data may be derived from the script, interviews, field notes, photographs, videotapes, personal documents;

7. The most importance of the process than the result, in the study of language there is a process to distinguish itself with prosede like morphological process will involve the basic shape before the results of the process, but in prosede did not ask where its basic form;

8. Limits specified by the focus, determination of focus is an attempt (dence) fatherly demarcate research; 
9. The specific criteria determining the validity of the data with the interests of the research itself;

10. Negotiated element/agreed outcome can be considered particularly from researchers and human element which is used as a data source.

In processing the data, the writer uses descriptive method to describe, explains the method that simply looks with the intensive accurately at the phenomena at the moment and then describes precisely what researcher sees. The writer uses this method because of the writer gain a better understanding of a topic. Descriptive research is the exploration of the existing certain phenomena. Descriptive are aimed at finding out "what is", so observational and surveys methods are frequently use to collect descriptive data..

\section{RESULTS AND DISCUSSION}

There are several results of the research, they are as follows.

a. The change from fonem /i/ become /e/ in medial

Vowel /i/ in medial words of Indonesia language change into vowel /e/ in utterance of India people in Padang's word.

$\begin{array}{llll}\text { NO. } & \text { BI } & \text { INDIA } & \text { MEANING } \\ 1 . & \text { air } & \text { [aer] } & \text { water } \\ 2 . & \text { baik } & \text { [bae?] } & \text { good } \\ 3 . & \text { balik } & \text { [bale?] } & \text { back } \\ \text { 4. } & \text { kecil } & \text { [kete?] } & \text { small } \\ 5 . & \text { lain } & \text { [laen] } & \text { other }\end{array}$

b. Disapperance /h/ in final

In vowel-vowel sequences, a front vowel deletes when it is adjacent to a back vowel regardless of the order of the vowels. The fact that a back vowel is maintained over a front vowel indicates that its place feature is marked with respect to that of the front vowel.

$\begin{array}{llll}\text { NO. } & \text { BI } & \text { INDIA } & \text { MEANING } \\ 1 . & \text { ayah } & \text { [aya] } & \text { father } \\ 2 . & \text { basah } & \text { [basa] } & \text { wet } \\ \text { 3. } & \text { belah } & \text { [bala] } & \text { cleave } \\ \text { 4. } & \text { benih } & \text { [beni] } & \text { seed } \\ 5 . & \text { buah } & \text { [bua] } & \text { fruit }\end{array}$

c. Disapperance $/ \mathrm{h} /$ in initial

The consonant $/ \mathrm{h} /$ in initial word disappear and replace it to the vowel /i/ after the consonant.

$\begin{array}{llll}\text { NO } & \text { BI } & \text { INDIA } & \text { MEANING } \\ 1 . & \text { hidung } & \text { [iduy] } & \text { nose } \\ 2 . & \text { hidup } & \text { [idui?] } & \text { alive }\end{array}$




$\begin{array}{llll}\text { 3. } & \text { hijau } & \text { [ijau }] & \text { green } \\ 4 . & \text { hisap } & \text { [iso?] } & \text { suction } \\ 5 . & \text { hitam } & \text { [itam }] & \text { black }\end{array}$

d. Disapperance $/ \mathrm{h} /$ in medial

The consonant $/ \mathrm{h} /$ disappear and followed by the vowel /a,i,u/ between the consonant. The writer can conclude that consonant $/ \mathrm{h} /$ does not appear in BIKI.

$\begin{array}{llll}\text { NO } & \text { BI } & \text { INDIA } & \text { MEANING } \\ \text { 1. } & \text { jahit } & \text { [jai?] } & \text { sew } \\ \text { 2. } & \text { matahari } & \text { [matoari] } & \text { sun } \\ 3 . & \text { tahu } & \text { [tau } & \text { know } \\ \text { 4. } & \text { tahun } & \text { [taun] } & \text { year }\end{array}$

e. Disapperance $/ \mathrm{r} /$ in final

Consonant $/ \mathrm{r}$ / disappear in final word, then vowel /a/ before the consonant replace it.

$\begin{array}{llll}\text { NO } & \text { BI } & \text { INDIA } & \text { MEANIG } \\ 1 . & \text { akar } & \text { [aka] } & \text { root } \\ 2 . & \text { bakar } & \text { [baka] } & \text { burn } \\ \text { 3. } & \text { dengar } & \text { [dana] } & \text { listen } \\ \text { 4. } & \text { ekor } & \text { [ikua] } & \text { tail } \\ 5 . & \text { lebar } & \text { [leba] } & \text { wide }\end{array}$

f. Disapperance $/ \mathrm{r} /$ in medial

Vowel /e/ followed by consonant/r/ absorp into vowel /a/, then consonant/r/ disappear and replace by consonant $/ \mathrm{b} /$. The writer have find that consonant $/ \mathrm{r} /$ appear in initial position.

$\begin{array}{llll}\text { NO } & \text { BI } & \text { INDIA } & \text { MEANING } \\ 1 . & \text { terbang } & \text { [tabay] } & \text { fly } \\ 2 . & \text { berbulu } & \text { [babulu] } & \text { hairy } \\ 3 . & \text { terbenam } & \text { [tabanam] } & \text { drown }\end{array}$

g. Absorption /at/ become /?/ in final

Vowel /a/ followed by consonant /t/ absorp to vowel /e/ and followed by glottal stop /?/.

$\begin{array}{llll}\text { NO } & \text { BI } & \text { INDIA } & \text { MEANING } \\ \text { 1. } & \text { berat } & \text { [bare?] } & \text { heavy } \\ \text { 2. } & \text { dekat } & \text { [dake?] } & \text { near } \\ \text { 3. } & \text { empat } & \text { [ampe?] } & \text { four } \\ \text { 4. } & \text { ulat } & \text { [ule?] } & \text { worm } \\ \text { 5. } & \text { hangat } & \text { [aye?] } & \text { warm }\end{array}$

h. Absorption /u/ become /o/ in medial

The absorption of fonem $/ \mathrm{u} /$ to become $/ \mathrm{o} /$ in medial, it occurs in medial position. The correspondence can be seen in the examplesbellow.

$\begin{array}{llll}\text { NO } & \text { BI } & \text { INDIA } & \text { MEANING } \\ 1 . & \text { hitung } & \text { [eton] } & \text { count }\end{array}$


$\begin{array}{llll}2 . & \text { jatuh } & \text { [jato }] & \text { fall } \\ 3 . & \text { jauh } & \text { [jao] } & \text { far }\end{array}$

From the data above, data 1 and 2 have the same change, which consonant $/ \mathrm{t} /$ followed by vowel $/ \mathrm{u} /$ and change into same consonant but different vowel which is $/ \mathrm{o} /$. The data 3 , there is vowel $/ \mathrm{a} /$ and consonant $/ \mathrm{h} /$ between vowel $/ \mathrm{u} /$. The changing $/ \mathrm{u} /$ become vowel /o/ and consonant $/ \mathrm{h} /$ disappear

i. Absorption $/ \mathrm{au} / \mathrm{become} / \mathrm{o} / \mathrm{in}$ final

The absorption $/ \mathrm{u} /$ become $/ \mathrm{o} /$ occurs at the final position in their environment.

$\begin{array}{llll}\text { NO } & \text { BI } & \text { INDIA } & \text { MEANING } \\ 1 . & \text { kalau } & {[\text { kalo] }} & \text { if } \\ 2 . & \text { bangau } & {[\text { bayo }]} & \text { stork }\end{array}$

Vowel /au/ absorp into vowel /o/ in final word like the data above.

j. Absorption $/ \mathrm{t} /$ become $/ \mathrm{k} /$ in final

Vowel /a/, /i/, /u/ followed by consonant /t/ absorp and change. Vowel /a/ and consonant /t/ change to vowel /e/ and glottal stop /?/. Vowel /i / followed by consonant /t/ change to vowel /i/ and glottal stop /?/. Vowel /u/ followed by consonant/t/ change into vowel /u/ followed by additional vowel /i/ and glottal stop /?/.

$\begin{array}{llll}\text { NO } & \text { BI } & \text { INDIA } & \text { MEANING } \\ \text { 1. } & \text { empat } & \text { [ampe?] } & \text { four } \\ \text { 2. } & \text { gigit } & \text { [gigi?] } & \text { bite } \\ \text { 3. } & \text { Ikat } & \text { [ike?] } & \text { tight } \\ \text { 4. } & \text { Jahit } & \text { [jai?] } & \text { knit } \\ \text { 5. } & \text { Kabut } & \text { [kabui?] } & \text { fog }\end{array}$

k. Absorption /a/ become $/ \mathrm{o} /$ in final

The absorption of fonem $/ \mathrm{a} /$ become $/ \mathrm{o} /$ infinalposition can be seen in the following data.

$\begin{array}{llll}\text { NO } & \text { BI } & \text { INDIA } & \text { MEANING } \\ 1 . & \text { apa } & \text { [apo] } & \text { what } \\ 2 . & \text { bunga } & \text { [buyo] } & \text { flower } \\ 3 . & \text { dua } & \text { [duo] } & \text { two }\end{array}$

Consonant $/ \mathrm{p} /$ foloowed by vowel $/ \mathrm{a} /$ in final word change into $/ \mathrm{o} /$. Consonant $/ \mathrm{y} /$ followed by vowel /a/ change into /o/. Vowel /u/ followed by vowel /a/, change into vowel $/ \mathrm{o} /$.

1. Absorption /p/ become / $/ \mathrm{k}$

Vowel /a/ in medial followed by consonant /p/ in final word absorp into vowel /o/ and glottal stop /?/.

$\begin{array}{llll}\text { NO } & \text { BI } & \text { INDIA } & \text { MEANING } \\ 1 . & \text { suap (me) } & \text { [suo?] } & \text { bribe } \\ \text { 2. } & \text { sayap } & \text { [sayo?] } & \text { wing }\end{array}$


$\mathrm{m}$. Absorption / $\mathrm{y} /$ become /ay/ in final

Vowel /u,i,a/ in medial followed by consonant $/ \mathrm{y} /$ in final word change and there is an additional vowel $/ \mathrm{a} /$ between vowel $/ \mathrm{u}, \mathrm{i}, \mathrm{a} /$ and consonant $/ \mathrm{y} /$. The writer have find that consonant $/ \mathrm{y} /$ appear only in final and medial position.

$\begin{array}{llll}\text { NO } & \text { BI } & \text { INDIA } & \text { MEANING } \\ \text { 1. } & \text { apung }(\mathrm{me}) & \text { [apuan] } & \text { float } \\ \text { 2. } & \text { cacing } & \text { [caciay] } & \text { worm } \\ \text { 3. } & \text { daging } & \text { [dagian] } & \text { meat } \\ \text { 4. } & \text { gunung } & \text { [gunuay] } & \text { mountain } \\ 5 . & \text { jantung } & \text { [jantuan] } & \text { heart }\end{array}$

n. The absorption from fonem /e/ become fonem /a/ in medial

The absorption from fonem /e/ become fonem /a/ in medial can be seen at the data follow.

$\begin{array}{llll}\text { NO } & \text { BI } & \text { INDIA } & \text { MEANING } \\ 1 . & \text { belah }(\mathrm{me}) & \text { [bala] } & \text { split } \\ 2 . & \text { benar } & \text { [batua] } & \text { correct } \\ 3 . & \text { bengkak } & \text { [bangka?] } & \text { swollen } \\ \text { 4. } & \text { benih } & \text { [bania] } & \text { seed } \\ 5 . & \text { berat } & \text { [bare?] } & \text { weight }\end{array}$

Consonant /b/ followed by vowel /e/ in medial word change to the consonant $/ \mathrm{b} /$ and vowel /a/.

o. Absorption /e/ become /a/ in initial

Consonant /e/ in initial word followed by consonant $/ \mathrm{n}, \mathrm{m} /$ change to vowel $/ \mathrm{a} /$ in initial word.

$\begin{array}{llll}\text { NO } & \text { BI } & \text { INDIA } & \text { MEANING } \\ \text { 1. } & \text { empat belas } & \text { [ampe? bale] } & \text { fourteen } \\ \text { 2. } & \text { empat puluh } & \text { [ampe? pulua] } & \text { forty } \\ \text { 3. } & \text { enam } & \text { [anam] } & \text { six } \\ \text { 4. } & \text { enam belas } & \text { [anam bale] } & \text { sixteen } \\ 5 . & \text { enam puluh } & \text { [anam pulua] } & \text { sixty }\end{array}$

p. Disapperance /e/ in medial

Vowel /e/ disappear in medial word if the consonant meet the consonant like the data below. The writer have find that vowel /e/ appear in initial and final position.

$\begin{array}{llll}\text { NO } & \text { BI } & \text { INDIA } & \text { MEANIN } \\ \text { 1. } & \text { peras } & \text { [pras] } & \text { squeeze } \\ \text { 2. } & \text { geraham } & \text { [graam] } & \text { molar } \\ 3 . & \text { keringat } & \text { [kringe?] } & \text { sweat } \\ \text { 4. } & \text { kerongkongan } & \text { [kronkoyan] } & \text { throat } \\ 5 . & \text { pelipis } & \text { [plipis] } & \text { temple }\end{array}$


q. Disapperance /d/ in initial

Consonant /d/ followed by vowel /e/ absorp then change. Consonant /d/ disappear and vowel /e/ change to vowel /a/, but the data 3 consonant /d/ and vowel /e/ disappear and replace with consonant /1/. Consonant/d/ does not appear in final position.

$\begin{array}{llll}\text { NO } & \text { BI } & \text { INDIA } & \text { MEANING } \\ 1 . & \text { debu } & {[\mathrm{abu}]} & \text { dust } \\ \text { 2. } & \text { debu } & \text { [abu] } & \text { dust } \\ 3 . & \text { delapan puluh } & \text { [lapan pulua] } & \text { eighty }\end{array}$

r. Disapperance /d/ in medial

Phoneme /d/ will disappear when it is in medial posistion.

$\begin{array}{llll}\text { NO } & \text { BI } & \text { BIKI } & \text { MEANING } \\ 1 . & \text { pendek } & \text { Pute } & \text { short } \\ \text { 2. } & \text { sedikit } & \text { [konjon] } & \text { a bit } \\ \text { 3. } & \text { tidur } & \text { [partu] } & \text { sleep } \\ \text { 4. } & \text { kodok } & \text { [konce?] } & \text { frog } \\ 5 . & \text { sudah } & \text { [ala] } & \text { done }\end{array}$

From the data 1 (153), vowel /e/ in medial change into vowel /u/, consonant /d/ disappear and replace with consonant $/ \mathrm{t} /$, and consonant $/ \mathrm{k} /$ also disappear. Data 2 and 3 totally change from the basic vocabularies. From data 4 (620) consonant /d/ disappear in medial and replace it into the additional consonant $/ \mathrm{n} / \mathrm{and} / \mathrm{c} /$, vowel $/ \mathrm{o} /$ in medial change into /e/. Data 5 (1110) consonant /s/ in initial word, /d/ in medial and /h/ in final disappear then change into consonant /1/ in medial.

s. Disapperance $/ \mathrm{p} /$ in final

Poneme /p/ will disappear when it is in teh final position, such as the data below.

$\begin{array}{llll}\text { NO } & \text { BI } & \text { BIKI } & \text { MEANING } \\ \text { 1. } & \text { asap } & \text { [aso?] } & \text { fog } \\ \text { 2. } & \text { hidup } & \text { [idui?] } & \text { alive } \\ \text { 3. } & \text { hisap } & \text { [iso?] } & \text { suction } \\ \text { 4. } & \text { sayap } & \text { [sayo?] } & \text { wing } \\ \text { 5. } & \text { suap (me) } & \text { [suo?] } & \text { bribe }\end{array}$

Vowel /a/ in medial word followed by consonant $/ \mathrm{p} /$ in final absorp into vowel $/ \mathrm{o} /$ and glottal stop /?/. Vowel /u/ in medial followed by consonant /p/ absorp into vowel /u/ and additional vowel /i/ and change into glottal stop /?/. consonant /p/ appear in initial and medial position and very productive.

\section{Code Mixing That Occur on India Ethnic in Padang}

Code mixing plays a very significant role in language change and language variation, and also provides an insight into the socio-cultural phenomena taking place in that area or region, through the linguistic choices of the people. It is not only an indicator that the process of change is going on, but also a vehicle of linguistic change. Indeed, many linguists view mixed-code as 
an inevitable by-product of bilingualism. The writer will explain the code mixing in language utterance among India people in Padang into three parts, which are hybridization, language acquisition, and fused lect.

\section{Language Hybridization of India Ethnic}

Language hybridization is a resultant process of frequent code-mixing. Sometimes, even the grammar or structure of one language is applied to the vocabulary of another. So when two or more languages are frequently mixed, resultantly a new hybrid variety of language takes birth. This new variety to some extent shares the qualities of both the languages but it has its own independent grammar and vocabulary that may not match any of the mixed languages.

1) Karaki blanjo di sinan, cik.

Mahal belanja di sana, kak.

'The market there is expensive, sist'

From the data above, the speaker make a hybridized noun phrase by adding the original word and the modifier from Bmk. "Karaki" from the original word of India people use means expensive, "blanjo" means shopping come from Minangkabau language, "di sinan" means to explain the place overthere which come from Minang, then "cik" means sis, such a nickname to call someone.

2) Pomle dorang nala

Kekasih anda canti

'your girlfriend is beautiful'

The speaker sandwiching the original language between the language that influence by Tionghoa Padang. "Dorang'" means you, it from Tionghoa Padang influence. "Pomle", means boyfriend or girlfriend. While "nala" means pretty.

3) Payan alah partu

Dia sudah mengantuk

'He has slept'

The hybridized noun phrases are made by sandwiching the item of the original language between Minangkabau language. "Payan" is for subject, "alah" means done which come from Minangkabau language, and "partu" means sleepy.

4) Lah soru lu?

Kamu sudah makan?

'Have you eaten?'

The hybridized sentences are made by Minangkabau language, the original language and Tiongpa influence. "lah" means have you done it before or not. Soru is from the original language means eat. "Lu" is subject or you, which come from Hokkian language, but Tionghoa Padang absorp it while they speak, until it becomes a habit to used.

5) Hukar di siko se lah aweng

Saya duduk disini saja 
'I sit here'

The hybridizes are made by sandwiching the original language between the Minangkabau language. "hukar" means sit which come from the original language, "di siko" come from Minangkabau language means here, " se lah" come from Minang which just as additional words for talk. "aweng" means subject I which come from the original language.

Code-mixing and language hybridization are interesting phenomena in bilingual societies that gain significance in the backdrop of globalization. Since majority of people in the city have a very superficial and limited understanding of the original language those who know the original language frequently code mix it in Minang, Indonesia, and Tionghoa Padang to exhibit their superior knowledge of the original language.

In such cases the speaker repeats the original language equivalent of the used word to express his knowledge of original language since the original language is a language of prestige and to differs the India people from another community. Another reason in such cases is that the original language equivalent of the word or term is more popular in society.

\section{Language Acquisition of India Ethnic in Padang}

Language acquisition is the process by which humans acquire the capacity to perceive and comprehend language, as well as to produce and use words and sentences to communicate. Language acquisition is one of the quintessential human traits, because non-humans do not communicate by using language. Language acquisition usually refers to first-language acquisition, which studies infants' acquisition of their native language. This is distinguished from second-language acquisition, which deals with the acquisition (in both children and adults) of additional languages.

The capacity to successfully use language requires one to acquire a range of tools including phonology, morphology, syntax, semantics, and an extensive vocabulary. Language can be vocalized as in speech, or manual as in sign. Human language capacity is represented in the brain. Even though human language capacity is finite, one can say and understand an infinite number of sentences, which is based on a syntactic principle called recursion. Evidence suggests that every individual has three recursive mechanisms that allow sentences to go indeterminately. These three mechanisms are: relativization, complementation and coordination. Furthermore, there are actually two main guiding principles in first-language acquisition, that is, speech perception always precedes speech production and the gradually evolving system by which a child learns a language is built up one step at a time, beginning with the distinction between individual phonemes.

The capacity to acquire the ability to incorporate the pronunciation of new words depends upon many factors. Before anything the learner needs to be able to hear what they are attempting to pronounce. Another is the capacity to engage in speech repetition. Children with reduced abilities to repeat nonwords (a marker of speech repetition abilities) show a slower rate of vocabulary expansion than children for whom this is easy. It has been proposed that the elementary units of speech have been selected to enhance the ease with which sound and visual 
input can be mapped into motor vocalization.Several computational models of vocabulary acquisition have been proposed so far. Various studies have shown that the size of a child's vocabulary by the age of 24 months correlates with the child's future development and language skills. A lack of language richness by this age has detrimental and long-term effects on the child's cognitive development, which is why it is so important for parents to engage their infants in language. If a child knows fifty words or less by the age of 24 months, he or she is classified as a late-talker and future language development, like vocabulary expansion and the organization of grammar, is likely to be slower and stunted.

Two more crucial elements of vocabulary acquisition are word segmentation and statistical learning (described above). Word segmentation, or the segmentation of words and syllables from fluent speech can be accomplished by eight-month-old infants. By the time infants are 17months-old, they are able to link meaning to segmented words.

Recent evidence also suggests that motor skills and experiences may influence vocabulary acquisition during infancy. Specifically, learning to sit independently between 3 and 5 months has been found to predict receptive vocabulary at both 10 and 14 months of age, and independent walking skills have been found to correlate with language skills around 10 to 14 months of age. These findings show that language acquisition is an embodied process that is influenced by a child's overall motor abilities and development.

\section{Fused Lect of India Ethnic in Padang}

Code mixing as the fuse lect has no specific meaning in the local context. A fused lect is identical to a mixed language in terms of semantic and pragmatics, but fused lect allow less variation since they are fully grammaticalized. In other words, there are grammatical structure of the fused lect that determine which source-language element may occur.

A mixed language or a fused lect is a relatively stable mixture of two or more languages. What some linguists have described as "codeswitching as unmarked choice" or "frequent codeswitching" has more recently been described as "language mixing", or in the case of the most strictly grammaticalized forms as "fused lects".

In areas where code-switching among two or more languages is very common, it may become normal for words from both languages to be used together in everyday speech. Unlike code-switching, where a switch tends to occur at semantically or sociolinguistically meaningful junctures, this code-mixing has no specific meaning in the local context. A fused lect is identical to a mixed language in terms of semantics and pragmatics, but fused lects allow less variation since they are fully grammaticalized. In other words, there are grammatical structures of the fused lect that determine which source-language elements may occur. A mixed language is different from a creole language. Creoles are thought to develop from pidgins as they become nativized. Mixed languages develop from situations of code-switching. 


\section{The Formula of Code Mixing Uttered By India People in Padang}

The words part in four sub, there are the original language, the words that influence by tionghoa, words that influence by minang, and words that influence by indonesia.

The mother language of India people is Tamil, because they come from Tamil, South India. By the time, because of their need to communicate with others, they learn Minang language, and Indonesia. Their language have influence by three language and it is take more influence in language use. The writer have some conversation with the India people with different area in Padang, and it proves that language change.

\section{CONCLUSION}

After analyzing The Language Utterance Among India Community In Padang, the writer can conclude the analysis into three findings :

1. Describing the language change among India ethnic in Padang, the writer finds 19 disappearamce and absorption consonant also vowel that utter in India people in Padang. The changing is influence by Minangkabau language, Tionghoa Padang, and Indonesia play a big role of the changing.

2. Describing code mixing that occur on India people in Padang, the writer differ into three parts which are language hybridization, language acquisition, and fuse lect. In each part , the writer related the theory and the data which can conclude as a mixed code.

3. Describing the formula of code mixing uttered by India people in Padang, the writer have 24 formula that concludes from the data, that the formula is mixed by Minangkabau, Tionghoa Padang, and Indonesia.

\section{REFERENSI}

Aditiawarman, Mac. 2009. Bahasa Indonesia Penutur Etnis Tiong Pa. Padang: Lembaga Kajian Aset Budaya Indonesia Tonggak Tuo.

2009. Bahasa Tiong Pa Bahasa Minangkabau Juga. Padang: Lembaga Kajian Aset Budaya Indonesia Tonggak Tuo.

2009. Interferensi Bahasa Minangkabau dalam Pembentukan Bahasa

Tiong Pa. Padang: Lembaga Kajian Aset Budaya Indonesia Tonggak Tuo.

2009. Pengaruh Komunikasi antarkultur dalam Pembentukan Kata Sapa

Bahasa Tiong Pa. Padang: Lembaga Kajian Aset Budaya Indonesia Tonggak Tuo. 2009.

2013. O We Orang Padang O. Kehidupan Masyarakat Tiong Pa. Padang: Lembaga Kajian Aset Budaya Indonesia Tonggak Tuo 
Aitchison, Jean. 2001. Language Change Progress or Decay. Cambridgeshire: Cambridge University Press.

Brinton, J Laurel et al. 2005. Lexicalization and Language Change Research Surveys in Linguistic. Cambridge: Cambridge University Press.

Chamber, J.K et al. 2013. The Handbook of Language Variation And Change. New York City: A John Wiley \& Sons, Ltd., Publication.

Good, Jeff. 2008. Linguistic Universal and Language Change. Oxford: Oxford University Press.

Hickey, Raymond. 2003. Motive For Language Change. Cambridge: Cambridge University Press.

Holm, A. John. 2004. An Introduction to Pidgins and Creoles. Cambridge: Cambridge University Press.

Holmes, Janet. 2012. An Introduction into a Sociolinguistic. London: Routledge.

Leech, Geoffrey et al. 2009. Change in Contemporary English. Cambridge: Cambridge University Press.

Muysken, Peter. 2000. Bilingual Speech. Cambridge: Cambridge University Press.

Trask, R.L. 2010. Why Do Languages Change. Cambridge: Cambridge University Press. 